\title{
COMPENSATION SYSTEM PRECISION MANUFACTURING PARTS GYROSCOPIC INSTRUMENTS
}

\section{КОМПЕНСАЦЙНА СИСТЕМА ПРЕЦИЗІЙНОГО ВИГОТОВЛЕННЯ ДЕТАЛЕЙ ГІРОСКОПІЧНИХ ПРИЛАДІВ}

\author{
Ruslan O. Ivanenko ${ }^{1}$ \\ indior@ukr.net \\ ORCID: 0000-0002-1447-6275 \\ Serhii A. Murakhovskyi \\ ORCID: 0000-0001-6920-5715
}

\author{
Р. О. Іваненко ${ }^{1}$, \\ старший науковий співробітник \\ С. А. Мураховський ${ }^{2}$, \\ канд. техн. наук, доцент
}
${ }^{1}$ Ukrainian Research Institute of Special Equipment and Forensic Science of the Security Service of Ukraine, Kyiv ${ }^{2}$ National Technical University of Ukraine "Igor Sikorsky Kyiv Polytechnic Institute”, Kyiv
${ }^{1}$ Український науково-дослідний інститут спеціальної техніки та судових експертиз Служби безпеки України, м. Київ
${ }^{2}$ Національний технічний університет Украӥни
«Київський політехнічний інститут імені Ігоря Сікорського», м. Київ

\begin{abstract}
Article is devoted to issues related to the geometric precision cylindrical parts on lathes with systems of CNC. The possibility of obtaining high-precision geometric shapes of cylindrical form using complex adaptive system metalworking process. Particular attention should be paid to the condition of the cutting tool, because it is the most unreliable element of the technological processing system and its condition directly affects the quality of the surface layer and dimensional accuracy of the machining part. For turning, it is advisable to create a system of functional diagnostics that monitors the process. When creating a diagnostic system, you need to choose parameters that are easy to measure and carry all the necessary information about the process. As studies show, of the whole set of parameters that characterize the course of the cutting process, the most convenient is vibroacoustic emission. But an important element is the location of the sensor, as its incorrect installation introduces unwanted interference into the signal and does not allow to detect all components of the oscillating process. The final stage is the processing and analysis of the received signal. The most complete idea of the process can be obtained by considering the spectral characteristics of the received signal. Modern computer technology has high performance and allows real-time signal processing and obtain all the data we need. As a result of the analysis, the classification of registration registration devices is created, which allows to determine the requirements for the principles of constructing sensors, their necessary technical characteristics and aspects of application. The modern touching system should have a great performance (no worse than 100mx) and the ability to satisfactory location on the instrument or near it; It is determined that the most effective touching systems for monitoring the mechanical processing process should have the following information outputs to CNC technological equipment: presence; distance; contact; Tap quality; readiness, which increases the quality of precision technological processes of mechanical processing.
\end{abstract}

Key words: geometric precision; machining accuracy; gyroscopic devices; control system; acoustic sensor.

Анотація. Стаття присвячена питанням, пов'язаним з геометричною точністю виготовлення деталей циліндричної форми на токарних верстатах з системами СNC. Досліджується можливість отримання високоточних геометричних форм циліндричного вигляду за допомогою комплексної адаптивної системи процесом металообробки. Процес торкання є головним формотворчим фактором, який має безпосередній вплив на якість кінцевого продукту виробництва, а його контроль $є$ важливим фактором підтримки високоякісної технології. Особливу увагу необхідно приділяти стану різального інструменту, тому що він $є$ найбільш ненадійним елементом технологічної обробної системи, і від його стану безпосередньо залежить якість поверхневого шару і розмірна точність оброблювальної деталі. Для токарної обробки доцільно створення системи функціональної діагностики, яка відстежує перебіг процесу. Під час створення системи діагностики необхідно вибрати параметри, які легко виміряти і які несуть всю необхідну інформацію про процес. Як показують дослідження, з усього набору 
параметрів, що характеризують протікання процесу різання, найбільш зручною є віброакустична емісія. Але важливим елементом є місце установки датчика, оскільки неправильна його установка вносить небажані перешкоди в сигнал і не дозволяє виявити всі складники коливального процесу. Підсумковим етапом є обробка $\mathrm{i}$ аналіз отриманого сигналу. Найбільш повне уявлення про протікання процесу можна отримати, розглянувши спектральні характеристики отриманого сигналу. Сучасна обчислювальна техніка має високу продуктивність 1 дозволяє в режимі реального часу обробити сигнал і отримати всі необхідні нам дані.

У результаті проведеного аналізу створено класифікацію приладів реєстрації торкання, яка дозволяє визначити вимоги до принципів побудови систем датчиків, їх необхідні технічні характеристики та аспекти застосування; сучасна система торкання повинна мати велику швидкодію (не менше за 100 мкс) та можливість задовільного розташування на інструменті або поблизу нього; визначено, що найбільш ефективні системи торкання для контролю процесу механообробки повинні мати такі інформаційні виходи до CNC технологічного обладнання: присутність; відстань; торкання; якість торкання; готовність, що підвищує якість прецизійних технологічних процесів механообробки.

Ключові слова: геометрична точність; точність обробки; гіроскопічні прилади; система управління; акустичний датчик.

\section{INTRODUCTION}

The accuracy of the gyroscopic instruments is significantly influenced by technological factors: the quality of the assembly and manufacture of individual parts. In particular, these factors influence the characteristics of precision instruments: inertial systems, gyrocompass, angular velocity sensors. In addition, the accuracy and reliability of the gyroscopic instruments depends on properly selected parameters of their elements and components, as well as the layout and adjustment. In the suspension mounts and sensors of angular and linear movement, used in navigation devices and systems that are often used parts of cylindrical shape $[1 ; 2]$. Manufacturing precision parts such form directly affects the accuracy of the device itself, therefore, a need to develop specific technologies machining to ensure the required accuracy [3; 4]. And therefore there is a need in the industrial equipment with the ability to compensate for geometric errors, registered measuring equipment in real time.

The progress of new technological processes in the conditions of flexible automated systems and precision machinery and instrumentation requires an increase in the accuracy of the manufacture of parts and reliability of concomitant control of the metalworking process. Control of the state of mechanical processing contains the definition of the flow and boundary state of the cutting tool (wear, load, achievement of critical wear, seizure, destruction). It is known that the control of metalworking equipment and the working tool can be carried out with the help of direct or mediocre methods that are based on the measurement of emission physical phenomena that forms a material processing zone (that is, its destruction) $[1 ; 2]$ under such emission phenomena understand the power loads, Power of metal working, acoustic emission, electromagnetic emission, thermal emissions. Depending on the specific physical phenomenon, the degree of accuracy and reliability of control is obtained in the principle of operation of the cutting instrument. Direct control methods allow directly to obtain measurements of absolute values of the wear of the instrument and the size of the part. Methods of mediocre control allow you to determine different situations with a tool and are more comfortable in terms of signal control that comes from the cutting zone. But these methods have the disadvantages of the accuracy of measuring the wear of the instrument. The main disadvantage of all control devices is unsatisfactory performance of the state of the working tool. The most important of them is the speed of obtaining information about touching the tool and details in conditions of increased surface contamination. In such circumstances, it is necessary to determine the moment of touching the tool and details with a high speed; To analyze whether it really is touching the tool and detail and develop a tool stops (i.e., the driving system). After all these technological operations, it is necessary to stop the instrument. Between the coordinate of valid touch and the coordinate of the cutting tool, there will be a difference that depends on the speed of objects and time required to determine the fact of tapping, a solution to stop and braking. In this regard, it is the relevance of the development of superfast touching systems. Increasing the speed of the touch system makes it possible to build systems with precision characteristics of the analysis of access in conditions of pollution of equipment $[2 ; 3 ; 4]$.

\section{STATEMENT OF THE PROBLEM}

The problem that arises in the control precision machining, is to determine the values of strain components under the action of the cutting tool. The need for such theoretical and, as a consequence, practical calculations is that in order to adjust the primary form details must fulfill several conditions regarding the trajectory of the tool. In the opposite case, deformation details will be those that achieve the desired shape, and even more precision, you cannot. This question is answered controlled precision machining. A mathematical model was developed control algorithms and recommendations provide an opportunity to develop an automated system control precision machining parts. 


\section{АВТОМАТИЗАЦІЯ ТА КОМП'ЮТЕРНО-ІНТЕГРОВАНІ ТЕХНОЛОГІЇ № 1 2021}

Such automatic control elastic movements improve the process of machining parts gyroscopic devices by increasing productivity and precision machining parts, and create favorable conditions for multiple services.

Machining accuracy and ensure conduct of operations required for the design accuracy of calculations, based on their appointment to the cutting and the use of adaptive control systems. On CNC precision manufacturing form increased by adjusting the tool path.

So are actual work related to the research and development of technological methods to stabilize and control the size of the geometrical shape of cylindrical parts. After the analysis, design and technological features nonrigid shaft established causes and quantitative relationships deviation of the shape of parts. The regularities of the bending deformations nonrigid workpiece identified. The necessity and theoretically justified technological ways to control strain state (the position or shape of the elastic axis) of a nonrigid shaft directly in the cutting process. The models of the state and the r egularities of control with the flexural deformation of geometric errors in the cutting process is developed. The basis of control is necessary condition for the deflection at the point of application of the cutting force. Theoretically, under this condition provides compensation bending deformations and minimum deviation from cylindrical form. A mathematical model that predicts the maximum deviation of the shape of flex shaft, depending on their size, rigidity, and taken the cutting, which allows for the required accuracy of shafts directly during processing machining centers

High accuracy of treatment, obtains due to the complex trajectory of cutting tools, updating the error. For this purpose, turning center was equipped with a vibro-acoustic system, which defines the tool touches the workpiece up to 0.6 microns. Therefore there is a need to create a mathematical model so that a minimum amount of the tool touches the workpiece to get his trajectory correction, compensating for the existing error

\section{THEORETICAL MODEL}

Assuming that the thermal state of TPS (technological processing system) is stable during operation, the value $\delta_{t w}$ can be defined as:

$$
\delta_{t w}(x)=\delta_{s}(x)+\delta_{t}(x)+\delta_{w}(x),
$$

where $\delta_{s}(x), \delta_{t}(x), \delta_{w}(x)$-that's components of $\delta_{t w}(x)$ , resulting from the elastic deformation of the carrier assembly rotary tool magazine, host the chuck-spindle headstock, also in parts, respectively, under the action of the radial component of the cutting force $F_{y}$.

$$
\delta_{t}(x)=C_{t} F_{y},
$$

where $C_{\mathrm{t}}-$ it is elastic deformation node carrier rotary tool magazine in the direction Fy, observed with the cutting edge of the tool (fig. 1).

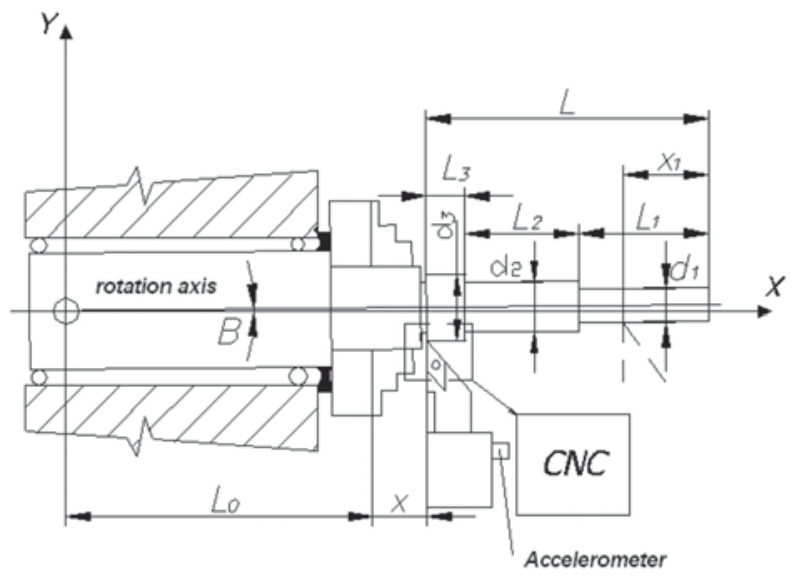

Fig. 1. Experimental Installation

Method of estimation of $\delta_{s}(x)$ can be obtained through the use of the concept of "center of rotation", described and evaluated in [1]. According to this concept, there is a center of rotation is located at a distance L0 behind the chuck and the elastic deformation of the chuck assembly-spindle-headstock can be roughly estimated as the rotational elastic deformation of $C_{r s}$ with the center of rotation. So

$$
\delta_{s}\left(L_{0}+x\right) \theta=\left(L_{0}+x\right)\left\{F_{y}\left(L_{0}+x\right) C_{r s}\right\}=C_{r s}\left(L_{0}+x\right)^{2} F_{y},(3)
$$

where $x$ - the distance between the current position of the tool and the front surface of the chuck to the spindle axis direction $\delta_{t}(x)$.

The system control precision machining device includes control of the cutting process the essence of which consists in separating the frequency band most intense vibroacoustic signal carrying out its logarithm, allocate certain bandwidth into a number of disjoint frequency bands. It uses bands and antiresonance, matching the natural frequency acoustical transducers, straighten signals and divide them into two streams and is compared with the set. Then memorize the instantaneous state of the first stream during certain specified time periods defined frequency bands and to simultaneously exceeding preset values determine the start of the cutting process, and the simultaneous fall signals the second group, below the threshold value is determined by the noise machine. Determine the termination of the cutting process, thus controlling the instantaneous signal status of the second group for a period of time determined by the transients at the beginning and end of the cutting process, and in the absence of simultaneous signals exceeding the second group of determining the authenticity of the start and end of the cutting process.

Cutting area is an active source of mechanical perturbations which are an integral part of the cutting process. The greatest intensity response of signal observed in the frequency range of $1-20 \mathrm{kHz}$ and this reaction, measured by piezoelectric accelerometers that are fixed in the vicinity of the cutting area and which can 


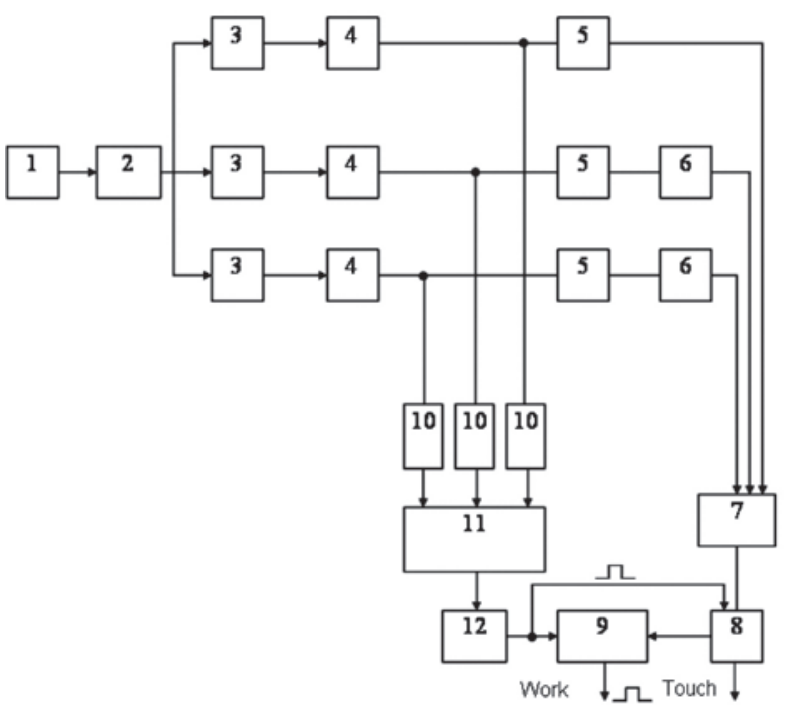

Fig. 2. Control device of the cutting process

be used to determine tool wear and defining moments of the beginning and ending cutting process, previously holding the identification process and establishing its relationship with parameters of the cutting process. This eliminates the need for additional vibration exciter.

Since the dynamic range of the signal changes can be $40-60 \mathrm{~dB}$, due to the great inconvenience by logarithmic amplifier exercising its logarithm in the frequency range of greatest signal strength. This allows you to compress the dynamic range and improve the performance of threshold devices.

Breaking into disjoint frequency band based on the identification process, the parameters of the TPS and parameters of input. The reaction system can be represented as regulation comb filter with mechanical amplificationzonesandareasofsignaldelayisantiresonance zones. If you combine one of the antiresonance areas with natural frequency piezoelectric transducer obtain the most sensitive part of the measured response with high statistical homogeneity and performance in a wide variation of parameters of the cutting process. The set of reactions in several frequency bands is the objective function is identified that can reliably control the start and end points of the cutting process.

Performance determines the moment of touching this method depends on the probability of simultaneous arrival of pulses at the threshold device. To increase performance is delayed or short-term (within ten microseconds) after storing threshold signals the first group.

The delay time is defined as the result parameter lowpass filter band.

\section{EXPERIMENTAL SYSTEM}

Piezoelectric transducer signals from the one specified in the cutting zone, enhanced logarithmic amplifier 2 and come to the block parallel band pass filters 3 and then straighten fullwave scheme 4, then the signals are divided into two streams and the first stream enters the threshold device first group of 5 and then
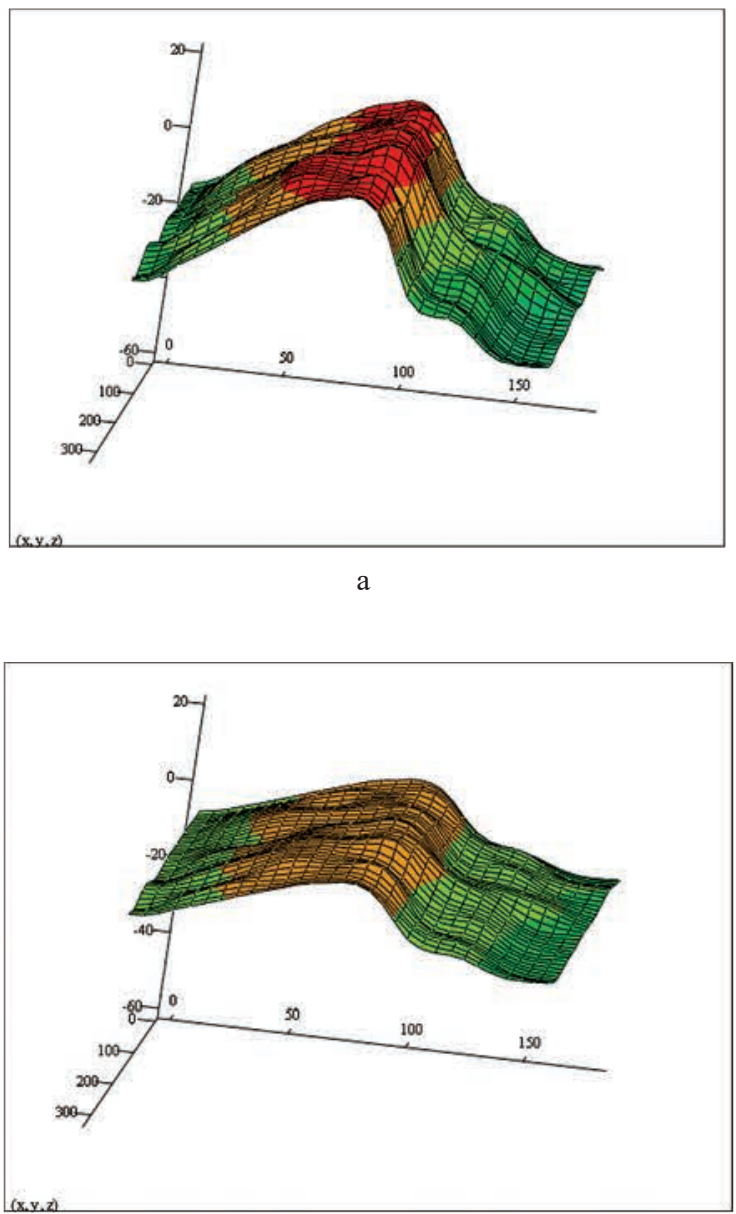

b

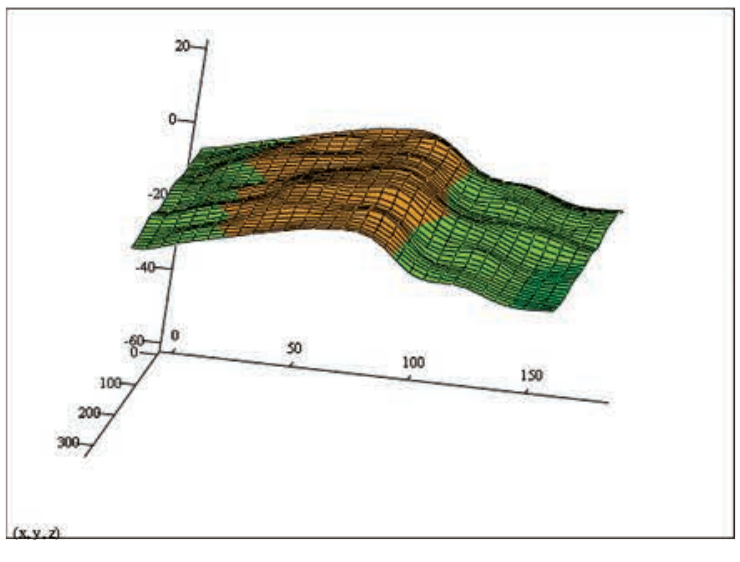

C

Fig. 3. Distribution of machining errors along the shaft type components in the application of the control system: a) first pass, b) second pass, c) third pass

the block of time delays 6 , with a delay not kept on all channels. This is necessary to the impulses coming from the rectifier can be eliminated in phase and threshold devices can operate simultaneously. Introduction delay or short memory post threshold states improves device performance many times (fig. 2). 
With the simultaneous flow of impulses from the line time delays triggered scheme matches 7 and activates the trigger touch 8 , which can be turned off in the case when the value of the output signal amplifier 2 are below the threshold level of the second group, in this case triggered scheme matches 11 and 12 turns on the device that generates a single pulse simultaneously to trigger off touch switch for 8 and logical unit 9, which makes checking failure device 12 within the time determined by the transition process. This is done to protect the device from touching the false positives caused by strikes, work arrangements and the like.

With the selection of frequency and bandwidth can be completely separated from the noise and false positives. It can be used as a reaction "system tools" and reaction "system of product".

The system can be implemented based on microelectronic technology as well as the sensing element can be used piezoelectric accelerometers or acoustic sensors that are sensitive receivers mechanical adverse effects that can be attached to the tool holders, calipers, spindles or desktop machine.

The results of processing without correcting the system and the application are shown in Fig. 3.

\section{CONCLUSIONS}

As a result, it was determined that the touch process is the main formative factor that has a direct impact on the quality of the final product, and its control is an important factor in maintaining high quality technology. As a result of the analysis, a touch registration system was created, which allows to determine the requirements for the principles of construction of sensor systems, their necessary technical characteristics and aspects of application.

The modern touch system must have high speed. It is determined that the most effective touch systems for control of the machining process should have the following information outputs to $\mathrm{CNC}$ process equipment: touch quality; contact; distance; readiness, which improves the quality of precision technological processes of machining. Experimental studies have been conducted, which have confirmed that the implementation of research results in production makes it possible to reduce the complexity of machining parts from $15 \%$ to $25 \%$.

Based the theoretical and experimental studies developed engineering recommendations for the design of technological processes on CNC machines, which will increase the accuracy of processing many times (depending on conditions) by reducing the errors of maximum contour processing caused by non-rigidity of the technological system.

Thus, the developed system enables the processing of parts to change the cutting conditions, to process results in the automatic mode for machining parts in multifunction equipment.

Developed a mathematical model to predict the maximum deviation of the shape nonrigid shaft, depending on their size, rigidity, and accepted the cutting as well as provide the required accuracy shafts directly during processing to processing centers.

\section{REFERENCES}

[1] Diorditsa I.M., Ostafev V.A. (2007). Povyshenie tochnosti detaley slozhnoy formy na tokarnykh obrabatyvayushchikh tsentrakh. [Improving the accuracy of complex parts on turning centers] Suchasni tekhnolohii u mashynobuduvanni: Do yuvileiu F. Ya. Yakubova: 36. nauk, statei / Ukladach A.I. Hrabchenko; Za red. A.I. Hrabchenko. Kharkiv: NTU "KhPI", S. 422-430 [in Ukrainian].

[2] Tymchik G.S., Diorditsa I.M., Skytsyuk V.I., Vysloukh S.P., Diorditsa A.M. (2010). Determination of Cylindrical Shape Parts With Solid Processing In Automatic Mode. XII International PHD Workshop OWD 2010. Under the auspices of Deans of Electrical, Electronic and Computer Science Faculties of Engineering, IEE - The Institution of Engineering and Technology IEEE - Institute of Electrical and Electronics Engineers - Polish Section. p. 116-120.

[3] Tymchyk H.S., Skytsiuk V.I., Vaintraub M.A., Klochko T.R. (2008). Vidchutnyky kontrolno-vymiriuvalnykh system [Sensors of control and measuring systems]: monohrafiia. Kyiv: NTUU "KPI", 240 s., Bibliohr.: 232-239 s. [in Ukrainian].

[4] Skytsiuk V.I., Diorditsa I.M., Naumenko, V.I. (2005). Vymiriuvannia formy detali za statychnoho roztashuvannia ta liniinoho determinovanoho rukhu rizalnoho instrumenta. [Measurement of the shape of the part with a static location and linear deterministic motion of the cutting tool] Zh. Visnyk NTUU "KPI". Seriia pryladobuduvannia. Vyp. 29. S. 69-76 [in Ukrainian].

\section{BIBLIOGRAPHY}

[1] Діордіца, В.А., Остафьев В.А. (2007). Повышение точности деталей сложной формы на токарных обрабатывающих центрах. Сучасні технології у машинобудуванні: До ювілею Ф. Я. Якубова: 36. наук. статей / Укладач А.І. Грабченко; За ред. А.І. Грабченко. Харків: НТУ «ХПІ», С. 422-430 с.

[2] Tymchik G.S., Diorditsa I.M., Skytsyuk V.I., Vysloukh S.P., Diorditsa A.M. (2010). Determination of Cylindrical Shape Parts With Solid Processing In Automatic Mode. XII International PHD Workshop OWD 2010. Under the auspices of Deans of Electrical, Electronic and Computer Science Faculties of Engineering, IEE - The Institution of Engineering and Technology IEEE - Institute of Electrical and Electronics Engineers - Polish Section. p. 116-120.

[3] Тимчик Г.С., Скицюк В.І., Вайнтрауб М.А., Клочко Т.Р. (2008). Відчутники контрольно-вимірювальних систем: монографія. Київ: НТУУ «КПІ», 240 с. Бібліогр.: 232-239 с.

[4] Скицюк В.І., Діордіца I.M., Науменко, В.І. (2005). Вимірювання форми деталі за статичного розташування та лінійного детермінованого руху різального інструмента. Вісник НТУУ «КПІ». Серія приладобудування. Вип. 29. С. 69-76.

(C) Іваненко Р. О., Мураховський С. А. Дата надходження статті до редакції: 12.03.2021 Дата затвердження статті до друку: 25.03.2021 